\title{
Promotion by the British pharmaceutical industry, 1983-8: a critical analysis of self regulation
}

\author{
Andrew Herxheimer, Joe Collier
}

\section{Abstract}

Since 1958 the Association of the British Pharmaceutical Industry (ABPI) has attempted to regulate the promotion of prescription medicines through its code of practice. This regulation is described and analysed for the six years 1983-8 using the reports on 302 complaints considered by its code of practice committee and annual reports.

The complaints came mainly from doctors (143, $48 \%$ ) and competing companies (103, 33\%). The committee found a total of 379 breaches of the code in $192(63 \%)$ of the complaints. Additional breaches were detected by informal scrutiny of advertisements by the ABPI secretariat. Analysis showed that $\mathbf{2 7 0}$ (71\%) of these breaches involved possible breaches of the Medicines Act. The rules that forbid misleading or unsubstantiated information and misleading claims or comparisons were broken most often. The committee found the most frequent offenders to be Organon (32 breaches), Smith Kline and French (23), Glaxo (21), A H Robins (18), Bayer (17), Merck Sharp and Dohme (17), and Lederle (16). Often the promotion of one product led to several breaches. The promotional wars over histamine $\mathrm{H}_{2}$ receptor antagonists accounted for 33 breaches.

It is estimated that in $1983-8$ about 100 breaches of the code were detected a year. In the 18 years 1972 88 the Medicines Act was breached probably over 1200 times. Health ministers, by not enforcing the regulations controlling promotion, have abrogated their responsibility to the ABPI, but the evidence suggests that the code has failed to deter promotional excesses. The ABPI's wish to secure compliance with the code seems weaker than its wish to pre-empt outside criticism and action: its self regulation seems to be a service to itself rather than to the public. It is suggested that the code of practice committee should become publicly accountable, that the majority of its members should represent the health professions and the public, and that effective sanctions are needed.

Department of Clinical Pharmacology and Therapeutics, Charing Cross and Westminster Medical School, London W6 8RF

Andrew Herxheimer, FRCP, senior lecturer

\section{Department of}

Pharmacology and Clinical

Pharmacology, St George's

Hospital Medical School,

London SW17 ORE

Joe Collier, FRCP, senior

lecturer

Correspondence to: $\mathrm{Dr}$ Herxheimer.

BrMed f 1990;300:307-11 they comply with the code's legal and technical requirements. Secondly, since 1985 a medical consul- tant to the ABPI has made an independent scrutiny of random advertisements, examining their medical and scientific content and on occasion asking companies for data to substantiate the claims or statements made. Possible breaches so identified are pursued by informal correspondence with the company concerned. Lastly, cases not resolved informally by the secretariat or the independent consultant are considered by the code of practice committee, which also deals with all complaints originating outside the ABPI. These are the only complaints that are reported in detail.

Until 1982 the ABPI revealed very little about the ways in which it policed promotion and implemented the code, publishing only a brief summary each year in its annual report. In 1982 and 1983 booklets were published summarising the cases the code of practice committee had considered since 1979, giving details of breaches of the code but not naming the offending companies. ${ }^{2}$ In 1983, after confidential reports for company chief executives had been leaked to Scrip, which specialises in news about the industry, the ABPI began to make the committee's full adjudications more available. Between January 1983 and October 1989 the committee produced about five detailed Reports to Chief Executives each year and sent copies to the Department of Health, Scrip, and the BMF. Twenty eight reports, covering 302 cases considered during this period, were issued up to October 1989. The cases relating to technical and legal issues are dealt with informally by the ABPI secretariat rather than the code of practice committee and are summarised without detail in the ABPI annual report. The cases dealt with by the medical consultant are not reported. We here review this material and assess the effectiveness of the industry's self regulation.

\section{Methods}

The cases considered by the code of practice committee between January 1983 and December 1988 and reported in its Reports to Chief Executives were analysed by the date of the complaint, the type of complainant, the company, the product, the type of promotion concerned, and the nature of the breaches found or alleged. Where the committee found a breach we assessed whether this might also amount to a breach of the Medicines Act 1968 or regulations made under it or whether it was simply a breach of those sections of the ABPI's own code that concern matters of professional conduct, fair competition, taste (for example, depictions of the female form), and the reputation of the pharmaceutical industry.

The Medicines Act forbids promotion that is "likely to mislead as to the nature or quality of medicinal products ... or as to their uses or "effects" (section 93 (7)). Several clauses in the ABPI code deal with this issue in different words and more detail-for example: 4.2 Information about medical products should accurately reflect current knowledge or responsible opinion. 
4.3 Information about medical products must be accurate balanced and must not mislead either directly or by implication.

4.4 Information must be capable of substantiation ...

5.1 Claims for a medical product must be based on an up-todate evaluation of all the evidence and must reflect this evidence accurately and clearly.

5.2 Exaggerated or all-embracing claims must not be made and superlatives must not be used. Claims should not imply that a medical product, or an active ingredient, has some special merit, quality, or property unless this can be substantiated.

5.3 Any statement about side-effects should be specific and based on data [provided] to the licensing authority, or on published data ... It should not be stated that a product has no side-effects, toxic hazards or risks of addiction. The word "safe" must not be used without qualification.

5.5 Comparisons of products must be factual, fair and capable of substantiation. In presenting a comparison, care must be taken to ensure that it does not mislead. . . '

We interpreted any finding by the code of practice committee that promotion was misleading (that is, breaches of the above rules) to indicate a possible breach of the Medicines Act.

The act (section 96) requires companies to provide practitioners with a data sheet before promoting a product to them. Clause 7.1 of the ABPI code of practice restates this. Clause 7.3(i) of the code concerns TABLE I - Number of breaches found by code of practice committee in
1983-8

\begin{tabular}{lcccc}
\hline & $\begin{array}{c}\text { No of possible } \\
\text { breaches of } \\
\text { Medicines Act }\end{array}$ & $\begin{array}{c}\text { No of breaches of } \\
\text { ABPI code only }\end{array}$ & $\begin{array}{c}\text { Total No } \\
\text { of breaches }\end{array}$ & $\begin{array}{c}\text { ro of complaints } \\
\text { reveaches breache }\end{array}$ \\
\hline 1983 & 27 & 16 & 43 & 26 \\
1984 & 35 & 28 & 63 & 31 \\
1985 & 44 & 16 & 60 & 33 \\
1986 & 51 & 10 & 61 & 34 \\
1987 & 66 & 12 & 78 & 31 \\
1988 & 47 & 27 & 74 & 37 \\
\hline Total & 270 & 109 & 379 & 192 \\
\end{tabular}

TABLE II -Number of cases dealt with under ABPI code

\begin{tabular}{lccc}
\hline & $\begin{array}{c}\text { No handled } \\
\text { informally }\end{array}$ & $\begin{array}{c}\text { No handled by code of } \\
\text { practice committee }\end{array}$ & Total \\
\hline 1983 & 37 & 39 & 76 \\
1984 & 33 & 55 & 88 \\
1985 & 19 & 48 & 67 \\
1986 & 33 & 52 & 85 \\
1987 & 31 & 51 & 82 \\
1988 & 12 & 57 & 69 \\
\hline Total & 165 & 302 & 467 \\
\hline
\end{tabular}

ॠExcludes cases handled by ABPI medical consultant.

TABLE III - Frequency of different types of breach found by code of practice committee

\begin{tabular}{|c|c|c|c|}
\hline $\begin{array}{l}\text { Section } \\
\text { of code' }\end{array}$ & Type of breach & $\begin{array}{l}\text { No of complaints } \\
\text { revealing such a breach }\end{array}$ & $\begin{array}{l}\text { Most frequent offenders } \\
\text { (No of occasions) }\end{array}$ \\
\hline 2 & Discredit brought on industry & 16 & $\begin{array}{l}\text { Ayerst (2), Bayer (2), } \\
\text { Winthrop (2) }\end{array}$ \\
\hline 4 & Misleading or unsubstantiated information & 58 & $\begin{array}{l}\text { Smith Kline and French } \\
\text { (9), Allen and Hanburys (6), } \\
\text { Glaxo (5) }\end{array}$ \\
\hline 5 & Misleading claim or comparison & 69 & Lederle (5), Organon (5) \\
\hline 6 & Disparaging reference to other company & 6 & \\
\hline 7 & Requirements for printed material not met & 39 & Lederle (5), Glaxo (4) \\
\hline $8 / 9$ & $\begin{array}{l}\text { Prohibited reference to official bodies or } \\
\text { NHS }\end{array}$ & 4 & \\
\hline 10 & Misleading artwork or graphs & 5 & \\
\hline 11 & Offences relating to reprints or quotations & 5 & \\
\hline 12 & $\begin{array}{l}\text { Distribution of printed promotional } \\
\text { material }\end{array}$ & 1 & \\
\hline 13 & $\begin{array}{l}\text { Information not provided with audiovisual } \\
\text { material }\end{array}$ & 8 & \\
\hline 15 & $\begin{array}{l}\text { Failure to certify printed promotional } \\
\text { material }\end{array}$ & 2 & \\
\hline 17 & Misconduct by medical representatives & 13 & Lederle (2) \\
\hline 18 & Offences concerned with samples & 5 & \\
\hline $19 / 20$ & Gifts, inducements, hospitality & 14 & Bayer (3) \\
\hline 21 & Promotion disguised as market research & 1 & \\
\hline 22 & $\begin{array}{l}\text { Promotion to the public (for example, press } \\
\text { conference) }\end{array}$ & 8 & \\
\hline
\end{tabular}

* Some complaints revealed more than one type of offence. points covered by the Medicines (Advertising to Medical and Dental Practitioners) Regulations 1978, which require that advertisements contain a clear, legible, and succinct statement of the entries in the data sheet relating, for example, to contraindications, precautions, and side effects. We therefore took breaches of any of these clauses to be possible breaches of the act.

Cases directly dealt with by the ABPI secretariat are not reported individually, so we analysed the collective data about these from the association's annual reports.

\section{Results}

In the six years 1983-8 the code of practice committee processed 302 complaints. They were submitted mainly by doctors ( 143 complaints, of which 63 were submitted by general practitioners), pharmaceutical companies (103), and pharmacists (27). Other sources included the Department of Health (6), consumer bodies (5), a member of parliament (1), and the ABPI itself (9). No source was mentioned for seven complaints.

The committee found breaches of the code in 192 (64\%) of the complaints, including $77(75 \%)$ of the complaints made by competing companies, 81 (57\%) of those from doctors, and 13 (48\%) from pharmacists.

Many of the complaints led the code of practice committee to identify more than one breach. In total the committee found 379 breaches, of which $270(71 \%)$ were possible breaches of the Medicines Act. Table I shows the number found in each year; on average two were found for each complaint upheld. In the six years the number of possible breaches of the act tended to increase, while the incidence of other breaches of the code showed no consistent trend.

Table II shows the numbers of complaints dealt with informally or by the code of practice committee from 1983 to 1988. The ABPI annual reports suggest that of the 165 "technical and legal" complaints made internally and handled informally up to the end of 1988,158 led to the identification of one or more breaches of the code, but the actual number is obscured by the ambiguous wording in the reports since 1985 , and the ABPI has told us that "only the code of practice committee can definitively rule whether there has been an actual breach of the code." Of the possible breaches identified by the ABPI secretariat, over $90 \%$ were admitted to be breaches by the company concerned.

\section{THE BREACHES FOUND}

The breaches involved all parts of the code (table III). The rules that forbid misleading or unsubstantiated information and misleading claims or comparisons were broken most often. Thirteen companies were found to have brought discredit on or reduced confidence in the pharmaceutical industry (clause 2).

The figure shows how many breaches of the code the committee identified for 64 individual companies. The companies figuring most prominently were Organon (32 breaches), Smith Kline French (23), Glaxo (including Allen and Hanburys, and Duncan Flockhart) (21), A H Robins (18), Bayer (17), Merck Sharp and Dohme (17), Lederle (16), Astra (14), May and Baker (11), and Pharmax (11). Fourteen companies were each represented by one breach; some did not appear at all. We found no clear relation between the size of a company or the size of its product range and the number of times the committee found it in breach of the code.

The highly skewed distribution of breaches among companies is partly explained by the finding that often the promotion of a single product led to a number of separate complaints and breaches of the code. Organon's promotion of Bolvidon led to three complaints ( 7 breaches) and that of Norcuron to two (25). Of the 10 complaints against Smith Kline and French, 


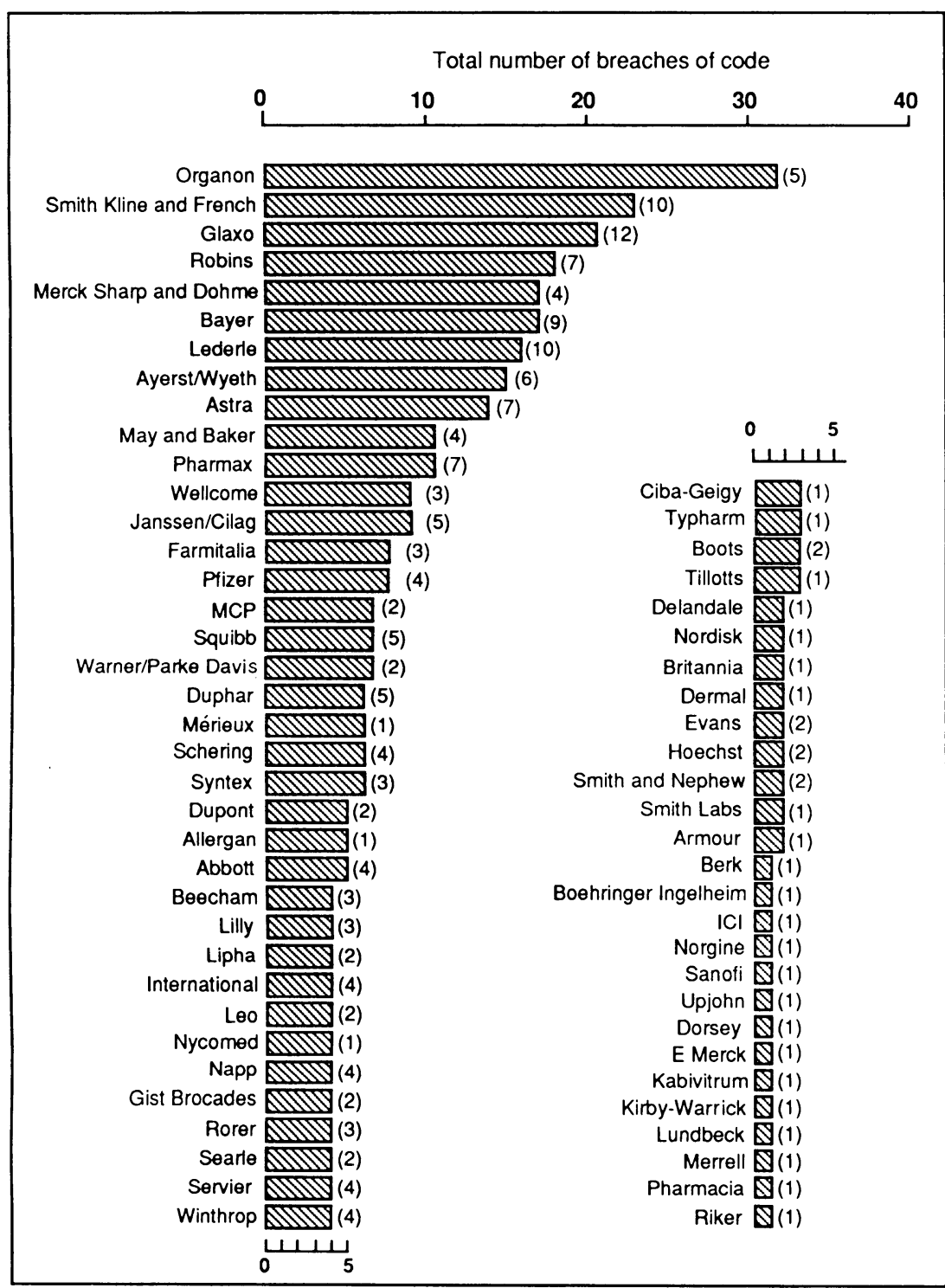

Number of breaches of ABPI code of practice identified by code of practice committee for individual pharmaceutical companies, 1983-8. Number of complaints revealing breaches is given in parentheses. Figures for Glaxo include those for its subsidiaries, Allen and Hanburys and Duncan Flockhart

six ( 14 breaches) concerned the promotion of Tagamet in $1983,1986,1987$, and 1988 and three concerned Engerix B. Of the 12 complaints against Glaxo, three (five breaches) concerned Zantac and three (five) Zinnat. The three major complaints against Merck Sharp and Dohme (14 breaches) were related to Pepcid PM. The promotional wars over histamine $\mathrm{H}_{2}$ receptor antagonists thus led to 33 identified breaches. Multiple proved complaints related to non-steroidal antiinflammatory drugs were fewer: Rheumox (manufactured by Robins), 2; Lederfen (Lederle), 4; Lodine (Ayerst), 2; Oruvail (May and Baker), 2.

\section{COMPLAINTS REJECTED BY THE CODE OF PRACTICE} COMMITTEE

Although the reports on rejected complaints give too little information to be analysed adequately, some examples illustrate where the committee draws the line. Under clause 18 of the code samples intended for treatment may be given to doctors only in response to a signed request. This is, however, not required for samples provided to help doctors to identify a product, which should contain only the minimum quantity necessary for this purpose. A doctor complained that at a postgraduate meeting samples of a product labelled "Trial Pack," containing three days' treatment, had been displayed on a company's stand for doctors to help themselves without needing to sign a request card.
The committee accepted the company's claim that the samples were provided for identification purposes and rejected the complaint.

Clause 19 of the code permits promotional gifts that are "inexpensive and relevant to the practice of medicine." The committee rejected eight complaints under this clause. Among the gifts the committee thought relevant to practice were a handmade mug, a book of cartoons depicting stressful situations, and a set of three walking sticks with stand. The cost of a Gladstone bag (about $£ 50$ ) was found acceptable as the company had offered only three as first prizes in a promotional competition. We note that the committee received no complaints about gifts of calculators or computers in connection with postmarketing surveil lance, which have been reported in the press, but such a complaint was upheld in 1989 , after the period covered in our review.

\section{Discussion}

Our review of the reports of the ABPI and its code of practice committee for the years 1983-8 showed that the code is commonly broken. It is not possible to discover exact numbers, but during this period about 550 breaches were noted and a further undeclared number would have been found by the ABPI's medica consultant and dealt with privately. A further considerable number must have escaped attention because few health professionals bother to complain to the ABPI. It has been rare for the same advertisement to attract more than one complaint. We estimate in round numbers that 600 breaches were detected in six years that is, about 100 a year. This may seem a small number in relation to the huge amount of promotion, but a single breach may represent an advertisement published many times. An advertisement hardly ever appears in only one issue of one journal. Where breaches of the Medicines Act are concerned, each separate act of publication (that is, in one issue of a journal) is a separate offence.

Our analysis suggests that over $70 \%$ of the breaches of the code identified by the committee ( 270 out of 379) also involved possible breaches of the Medicines Act; the proportion among those dealt with by the secretariat may be similar, but because the data are not published we could not analyse them. It can, however, be difficult to decide whether a breach of the code is also a possible breach of the act because points that essentially correspond have been drafted differently in the two texts. For this reason, wherever a voluntary code is being established the drafting should ensure that its relation to the law is clear and explicit.

The Medicines Act came into force in September 1971 , and if it is assumed that the incidence of breaches did not change between 1972 and 1988 we calculate that in that time it was breached probably around 1200 times. If compliance with the act improved during the 1970 s then this will be an underestimate. (A survey of journal advertisements in 1974 found many that lacked information required by the act,${ }^{+}$which suggests that this may have been the case.)

The breaches that most clearly show the thinking of the code of practice committee relate to promotion that is regarded as bringing the industry into disrepute. In 1986 Bayer's abuse of postmarketing surveillance ${ }^{5}$ was considered so serious that the ABPI took the ultimate and unprecedented step of suspending the company from its membership. ${ }^{6}$ Bayer was reinstated in 1987 but in 1988 committed another breach.? Organon's promotion of Norcuron, an intravenous muscle relaxant, was considered disreputable because a single complaint revealed 17 separate breaches of the code (and possibly of the act). ${ }^{8}$ Farmitalia Carlo Erba's promotion of Flosint, which included a trip on the 
Orient Express, ${ }^{90}$ and E Merck's withdrawal of research funding from a professor of surgery who refused to promote the use of the company's product in his hospital ${ }^{11}$ were also considered discreditable.

We did not attempt to assess the seriousness of different breaches ourselves because the criteria would inevitably be subjective. There might be general agreement about which were serious and which trivial but not on those in between. Neither the code nor the act indicates the gravity of different offences.

\section{NEGLECT BY MINISTERS}

The Medicines Act drew heavily on the recommendations of the Sainsbury report, ${ }^{12}$ which was primarily concerned with the control of pharmaceutical promotion. The act accordingly provides regulations for controlling promotion (sections 108-110) and makes health ministers responsible for enforcing them. Ministers have not fulfilled this duty, and by abrogating their responsibility to the ABPI they have allowed many hundreds of possible breaches to escape consideration by the criminal courts (for example, under section 93). The Department of Health's case is that the industry should for several reasons be encouraged to regulate itself: the industry has the expertise and is willing to do the work, and the department saves money and bureaucratic effort and avoids potentially troublesome confrontations with the industry, which it officially sponsors.

The department has been active on occasions. The most notable example was the prosecution of Roussel for making misleading claims about Surgam. ${ }^{1314}$ The code of practice committee did not deal with this case, probably because the ABPI learnt that a prosecution was pending. Gross misbehaviour may be dealt with informally and in secret within the medicines secretariat by expressing stern disapproval to the company, which may imply a threat of adverse publicity or the withdrawal of good will. This happened with Hoechst's warning letter to doctors about nomifensine, which was partly promotional and implicitly disparaged the Committee on Safety of Medicines. ${ }^{15}$ Another example was the promotion in 1988 of flecainide for an unlicensed indication by a representative. The department has both warned the industry as a whole $e^{1617}$ and reprimanded individual companies, but our findings suggest that this has not curbed promotional excesses. Last year's transformation of the medicines division of the Department of Health into the Medicines Control Agency seems unlikely to bring any change.

\section{THE INDUSTRY: COMPLACENT BUT NOT COMPLIANT}

The ABPI is proud of its code but seems blind to its shortcomings, claiming that "An outstanding feature has been the success of voluntary compliance with the provisions of the Code and acceptance of the rulings of the Committee. It has not been found necessary to apply sanctions to secure compliance because members of the association are anxious to ensure that their marketing activities conform to the highest standard." Nevertheless, during the period of our review the successful prosecution of Roussel, continuing public criticism of improper promotion, and official warnings from the Department of Health may have made the ABPI more active in monitoring advertisements and soliciting complaints. Our survey shows that companies are good at recognising breaches, but this has not led them to commit fewer of them. The data do not reveal any obvious deterrent effect of the code.

Even if voluntary compliance with the code were as successful as the ABPI claims, it must be noted that its standards are those determined by the industry; the public, which is endangered by misleading or otherwise incorrect promotion, is neither informed nor consulted. The ABPI's wish to secure compliance with the code seems far weaker than its wish to pre-empt outside criticism and action by showing its procedural consistency and efficiency-for example, by dealing with cases in an average time of 14 weeks. ${ }^{18}$ Outside complainants are given no opportunity of responding to defendants' arguments.

The ABPI gives virtually no adverse publicity to companies found to have breached the code. The only sanction it can impose is to suspend an offending company from membership of the association; this has been done once in 30 years. The ABPI requires an undertaking that the breach will not be repeated, but companies do not always seem to honour this. The ABPI has no power to require an offender to retract or correct a misleading statement.

This contrasts with the position in the United States, where the Food and Drug Administration (FDA) frequently issues "regulatory letters" to companies making false or misleading promotional claims, requiring corrective advertising or a "Dear Doctor" letter. However, an official of the FDA has recently said that "the vast majority" of promotional materials submitted for consideration by the FDA are false or misleading in some respect but that the agency can take regulatory action in only about $5 \%$ of cases, mainly because it lacks resources. ${ }^{19}$ The code of conduct of the Australian Pharmaceutical Manufacturers' Association (APMA) empowers its committee to ensure that an offending member issues a retraction statement, which is subject to approval in detail by the committee before release..$^{20}$ The Medical Fournal of Australia has recently begun to publish summaries of APMA decisions on violations of the code. The advertisements are identified and the action taken is specified-for example, "The advertisement (CGE482/CJB) and promotional booklet (CGE466/ CJB) by CIBA-GEIGY for Voltaren. Data were used selectively to draw a conclusion which was not supported by the literature presented. Action taken: the promotional literature was withdrawn. A statement of clarification was sent to all medical practitioners who had received the promotional booklet." ${ }^{21}$ These are modest steps in the right direction, but there is pressure for more effective corrections, public accountability, and a wider range of sanctions. .22-25 $^{2}$ There is no country yet in which promotion is satisfactorily controlled.

\section{THE FUTURE}

Drug promotion is important because it is a major determinant of prescribing patterns. ${ }^{12}$ Control in the United Kingdom is important not only for the domestic market but also because it is taken as a standard for export markets, especially for those in countries with weak controls of their own. How can the present control of promotion in the United Kingdom be improved?

Many of the problems would be solved if the health ministers chose to enforce the Medicines Act. The Department of Health would obviously require resources for enforcement, but even if these were provided standards could be maintained only if the professions - doctors, dentists, and pharmacists-also remained alert. There is much promotion that does not appear as the printed word, and the law regards the words spoken by company representatives exactly as it does printed promotional material. Anyone finding cause for complaint could get his or her member of parliament to write to the health minister.

The ABPI's self regulation seems to be a service to itself rather than to the public. We believe that the present system is unacceptable even for matters that fall outside the Medicines Act. The ABPI code of practice would still be needed to deal with matters of conduct outside the scope of the act, but the code of 
practice committee should become publicly accountable. Fewer than half its members should come from the industry: the majority should represent the health professions and the public. (The United Kingdom Advertising Standards Authority, which has analogous functions, has only a minority of members from the advertising industry.) Complainants should have the same right to be heard as defendants; hearings should be open to the public, reports published, and a mechanism for appeals introduced. Adequate self regulation needs teeth: it needs sanctions that work. If publicity and mandatory corrections are ineffective then fines may be needed. Changes along these lines should be made as soon as possible, and their efficacy monitored by an impartial body. Editors of journals carrying advertisements could play a special part by performing their own critical scrutiny and taking a more robustly independent line.

We thank Mr A D W Massam, secretary of the ABPI code of practice committee, for patiently answering our questions about the administration of the code.

1 Association of the British Pharmaceutical Industry. Code of practice for the pharmaceutical industry. In: ABPI data sheet compendium 1989-90. London: Datapharm, 1989:vii-xv. (6th ed, 1984; 7th ed, 1988.)

2 Association of the British Pharmaceutical Industry, Code of Practice Committee. Case reports. London: ABPI, 1982-3. (Vol 1, 1979 and 1980; Vol 2, 1981 tee. Case repo

3 Association of the British Pharmaceutical Industry. Case 786/1/89. Code of Practice: Reports to Chief Executives 1989;28:4-5.
4 Stimson GV. Information contained in drug advertisements. Br Med $\mathrm{f}$ 1975;iv:508-9.

Erlichman J. The bogus drugs testing at heart of sales drive aimed at GPS Guardian 1986; Sept 10:3.

6 Association of the British Pharmaceutical Industry. Case 640/9/86. Code of Practice: Reports to Chief Executives 1986;15:3-4.

Association of the British Pharmaceutical Industry. Case 775/11/88. Code of Practice: Reports to Chief Executives 1989;27:3.

8 Association of the British Pharmaceutical Industry. Case 712/12/87. Code of Practice: Reports to Chief Executives 1988;22:5-7.

Mangold T. Relationships between doctors and salesmen are lurching out of control. Listener 1983;110(20 Jan): 1-2.

10 Association of the British Pharmaceutical Industry. Case 459/4/83. Code of Practice: Reports to Chief Executives 1983;2:2-3.

11 Association of the British Pharmaceutical Industry. Case 566/4/85. Code of Practice: Reports to Chief Executives 1985;10:6-7.

12 Report of the Committee of Enquiry into the Relationship of the Pharmaceutical Industry with the National Health Service 1965-1967. London: HMSO, 1967. (Chairman Lord Sainsbury.) (Cmnd 3410.)

13 Collier J, Herxheimer A. Roussel convicted of misleading promotion. Lancet 1987; ;:113-4.

14 Collier J, Herxheimer A. Medicines Act passes crucial test. Lancet 1988;i:1349. 15 Anonymous. Trouble with nomifensine. Drug Ther Bull 1985;23:98-100.

16 Department of Health and Social Security. Promotion of medicines. Medicines Act Information Letter 1981 Sep:5. (No 31 )

17 Department of Health and Social Security. Advertising of medicinal products. Medicines Act Information Letter 1983 Sep:1. (No 38.)

18 Association of the British Pharmaceutical Industry. Annual report 1988-89. London: ABPI, 1989:43.

19 Anonymous. FDA's drug promotion problems. Scrip 198924 Feb: 14

20 Australian Pharmaceutical Manufacturers' Association. Code of conduct. Sydney: APMA, 1960. (Adopted 6 December 1988.)

21 Randall H. Drug promotional problems. Med F Aust 1988;149:713.

22 Randall H. Drug promotional problems. Med f Aust 1989;150:463.

23 Kwok YS, Sylvan L. Towards a national medicinal drug policy for Australic Canberra: Consumers' Health Forum of Australia, 1989:22-8.

24 Kwok YS, Sylvan L. Drug advertising. Med f Aust 1988;150:664.
25 Harvey K. Drug promotional problems. Med f Aust 1988;150:664-5.

(Accepted 21 December 1989)
Núcleo de Medicina

Tropical, Universidade de Brasilia-CP 153121, 70.010 Brasilia DF, Brazil P D Marsden, MD, professor

BrMed $\tau$ 1990;300:311-2

\section{Letter from Brasilia}

\section{Fertile flukes and mediating molluscs}

\section{P D Marsden}

We are at a school deep in the Brazilian interior on the borders of the state of Bahia with that of Gioás. A rural community of less than 200 people, the school is small and there is a single teacher. We have got permission from the mayor to examine the children today for schistosomiasis. As we enter the children stand, but I note that a little boy at the back has difficulty in standing up and getting out of his form-his belly is unusually large. The teacher has arranged a sort of examination couch made of desk tops, and I ask if I can examine that boy first. He comes forward slowly, kicks off his sandals, and lies on the desk top. His name is José, and he is 12 years old. Lifting up his shirt I can see that his abdomen is distended, though there are no visible dilated veins. On palpation I can show an enlarged spleen by ballottement but no liver. Percussion confirms the presence of a considerable ascites. $\mathrm{He}$ probably has advanced hepatosplenic schistosomiasis due to Schistosoma mansoni. The distribution of faecal pots is supervised by the teacher, and José goes to the bush (there is no lavatory) to return with a faecal specimen.

Outside, in the back of our transport, two technicians are processing stool specimens with the Kato quantitative technique. José's specimen shows a heavy infection with the laterally spined eggs of $S$ mansoni. Meanwhile inside, the routine clinical examination for hepatosplenomegaly continues. Eventually we have the preliminary results of our little survey. Over half the children have palpable livers or spleens, but the parasitology is even more impressive. The technicians examining stools find that only one child does not have the characteristic eggs.

The students are finishing up the protocols in the school and the technicians still documenting, preserv- ing, and storing the specimens for future reference. Accompanying my chief, Professor Aluízio Prata, we stroll down to the river. Like most of the areas where we work on schistosomiasis it is the only source of water for bathing, washing, and drinking. Later, in the heat of the day, we will see these same children bathing from the little beach. Looking under the vegetation hanging over the water we quickly find the vector snail Biomphalaria glabrata, and, putting two or three in a glass of water in the sunlight, we can just see the cercarias being shed by the snails into the water. This is the minute, tadpole like infective form for humans, which enters the skin within minutes to produce eventually the adult worm in the portal circulation. Fertile pairs of worms give rise to the characteristic eggs in the stool, and such eggs induce the severe portal fibrosis, producing presinusoidal portal hypertension as seen in José.

Theoretically you could break this parasitic life cycle at least at three points: the shedding of eggs into the environment, the snail, and humans. Rural Brazilians are often broadcast defecators, and latrine building has not been a great success. They get turned into storage rooms or chicken houses. Educational programmes are hard to implement. Like all mammals we live in an environment contaminated by our own faeces. It is a question of degree. Witness the famous unpublished experiment in an American middle class home where after the family had ingested fluorescein ultraviolet light picked up the dye on the mantelpiece, the cutlery, etc. The experiment was not published because the Americans are already obsessional about washing their hands and what else can you do?

So the eggs get into the water and the infective form for the snail, the miracidium, produces innumerable 